\title{
Salicylic Acid Induces Resistance to Alternaria solani in Hydroponically Grown Tomato
}

\author{
Matthew E. Spletzer and Alexander J. Enyedi
}

Department of Biological Sciences, 3927 Wood Hall, Western Michigan University, Kalamazoo 49008-3899.

Accepted for publication 18 May 1999.

\begin{abstract}
Spletzer, M. E., and Enyedi, A. J. 1999. Salicylic acid induces resistance to Alternaria solani in hydroponically grown tomato. Phytopathology 89: $722-727$.

Alternaria solani is the causal agent of early blight disease in tomato and is responsible for significant economic losses sustained by tomato producers each year. Because salicylic acid (SA) is an important signal molecule that plays a critical role in plant defense against pathogen invasion, we investigated if the exogenous application of SA would activate systemic acquired resistance (SAR) against $A$. solani in tomato leaves. The addition of $200 \mu \mathrm{M}$ SA to the root system significantly increased the endogenous SA content of leaves. Free SA levels increased 65-fold over basal

no visible phytotoxic effects. Total SA content (free SA + SA-glucose conjugate) increased to $108 \mu \mathrm{g} \mathrm{g}{ }^{-1} \mathrm{FW}$ after $48 \mathrm{~h}$. Concomitant with elevated $\mathrm{SA}$ levels, expression of the tomato pathogenesis-related (PR)-1B gene was strongly induced within $24 \mathrm{~h}$ of the addition of $200 \mu \mathrm{M}$ SA. PR-1B expression was still evident after $48 \mathrm{~h}$; however, PR-1B induction was not observed in plants not receiving SA treatment. Challenge inoculation of SA-treated tomato plants using conidia of A. solani resulted in $83 \%$ fewer lesions per leaf and a 77\% reduction in blighted leaf area as compared with control plants not receiving SA. Our data indicate that root feeding $200 \mu \mathrm{M}$ SA to tomato plants can (i) significantly elevate foliar SA levels, (ii) induce PR-1B gene expression, and (iii) activate SAR that is effective against $A$. solani.
\end{abstract} levels to $5.85 \mu \mathrm{g} \mathrm{g}^{-1}$ fresh weight (FW) after $48 \mathrm{~h}$. This level of SA had
Alternaria solani Sorauer is classified in the subdivision Deuteromycotina (imperfect fungi), class Hyphomycetes, and order Hyphales (1) and is the causal agent of early blight disease of commercially produced tomato, potato, and eggplant (16). Early blight may affect the foliage, stems, and fruits of infected plants (16) and is the most common leaf spot disease of tomato in the Central and Atlantic states. Early blight is responsible for a large proportion of total monetary losses sustained by tomato producers every growing season. If disease incidence is high, the fungus can cause extensive defoliation, leading to a reduction of economic fruit yield (16). Control of early blight disease has been accomplished primarily by the application of chemical fungicides, long crop rotations, pasteurizing seedbeds with steam or fumigants (16), and efforts directed toward breeding resistant tomato cultivars $(5,26)$. The lack of single-gene resistance and the complex patterns of inheritance have resulted in the availability of no commercial tomato cultivar that possesses adequate levels of resistance to $A$. solani (26).

As an alternative to fungicide application, it may be possible to utilize a scheme of inducible plant defenses in order to provide protection against $A$. solani in tomato. One such induced defense response known as systemic acquired resistance (SAR) could provide sufficient protection against this pathogen. SAR is classically defined as an induced system of resistance triggered by pathogens that cause rapid cellular necrosis of infected tissues $(6,15,30)$. Typically, the infection process activates disease resistance in the noninfected foliar tissue and provides long-lasting protection against a broad spectrum of disease-causing organisms $(15,30)$. SAR can be induced in tobacco and arabidopsis $(35,37)$ using the plant hormone salicylic acid (SA); however, no attempts have been made to examine the effects SA may have on disease susceptibility in tomato. There are several reports that SAR can be induced in tomato using biotic

Corresponding author: A. J. Enyedi; E-mail address: alex.enyedi@wmich.edu

Publication no. P-1999-0712-01R

(C) 1999 The American Phytopathological Society elicitors such as tobacco necrosis virus (3) or Phytophthora infestans $(8,13)$. In the case of $P$. infestans, the induced resistance may have some efficacy against $A$. solani (13). There are no reports that SAR can be induced in tomato using an elicitor derived from A. solani, although $A$. cassiae does have the capacity to induce SAR in the perennial weed Cassia obtusifolia (36).

The evocation of the SAR response causes the rapid accumulation of several pathogenesis-related (PR) protein families in the intracellular and extracellular regions of the leaf (35). Some of the PR proteins that accumulate during SAR have been demonstrated to have enzymatic activities (i.e., glucanase and chitinase) that coincide with defense mechanisms against fungal, viral, and bacterial pathogens $(17,19,22,27)$. Although the most abundant and tightly correlated molecular markers identified for SAR appear to be the family of PR-1 proteins (35), the precise biochemical function of these proteins remains to be elucidated $(2,27)$. The expression of PR genes and the induction of SAR can occur in the absence of pathogens by way of the application of synthetic compounds such as 2,6-dichloroisonicotinic acid (23,34) and benzothiadiazole-7carbothioic acid $(12,18)$; however, SA is the only plant-derived compound shown to induce SAR $(8,35,37)$. It is well established that the induction of SAR and the enhancement of disease resistance result from elevated endogenous tissue levels of SA $(11,21$, $24,35)$. In addition to the SAR that results from rising levels of SA in plants, the exogenous application of SA to plants can also effectively induce SAR $(29,35,37)$.

Recently, it was reported that petiole feeding dichloroisonicotinic acid or SA to excised tomato leaves increases PR protein mRNA expression (33). However, this report did not assay the changes in endogenous SA content in response to treatment nor was the development of SAR examined, since only detached leaves and not intact plants were utilized in the study (32). Consequently, the current investigation was undertaken to clarify the effect(s) of exogenous SA application to tomato and to investigate if SA has the capacity to induce SAR in tomato that is effective against $A$. solani. A hydroponic culture system was developed that allowed the con- 
trolled feeding of SA to intact tomato plants and, in turn, tissue analyses were performed to measure SA levels, PR-1 mRNA expression, and foliar response to pathogen infection.

\section{MATERIALS AND METHODS}

Plant materials. Seeds of tomato, Lycopersicon esculentum Mill. cv. Rutgers Select, were sown in artificial soil medium (MetroMix 510; Scotts-Sierra Horticultural Products Co., Marysville, OH) and grown to the 8-week stage in the greenhouse. Plants were removed from their pots, and the growing medium was washed away from the roots. Plants were then placed into an aerated hydroponics vessel constructed from a Magenta tissue culture box $(10 \mathrm{~cm}$ high $\times 6 \mathrm{~cm}$ wide $\times 6 \mathrm{~cm}$ long) (Sigma Chemical Co., St. Louis). The hydroponic vessel was painted black on the exterior to decrease light penetration in order to prevent algal growth in the liquid medium. Hydroponic vessels were supplied with $250 \mathrm{ml}$ of $0.5 \times$ Murashige \& Skoog (MS) (25) basal salts medium. Tomato plants were maintained under a 16-h photoperiod, supplied by six cool-white fluorescent lamps with $190 \mu \mathrm{m}$ of photons per $\mathrm{m}^{2}$ per s (PAR Detector PMA 2132; Solar Light Co., Philadelphia) at $24 \pm$ $1^{\circ} \mathrm{C}$. After a 2-day acclimation period following transfer to the hydroponic vessel, $200 \mu \mathrm{M}$ SA in $0.5 \times$ MS (MS+SA) was added to the appropriate vessels. MS and MS+SA solutions were exchanged daily to ensure a continuous supply of nutrients and SA. SA levels
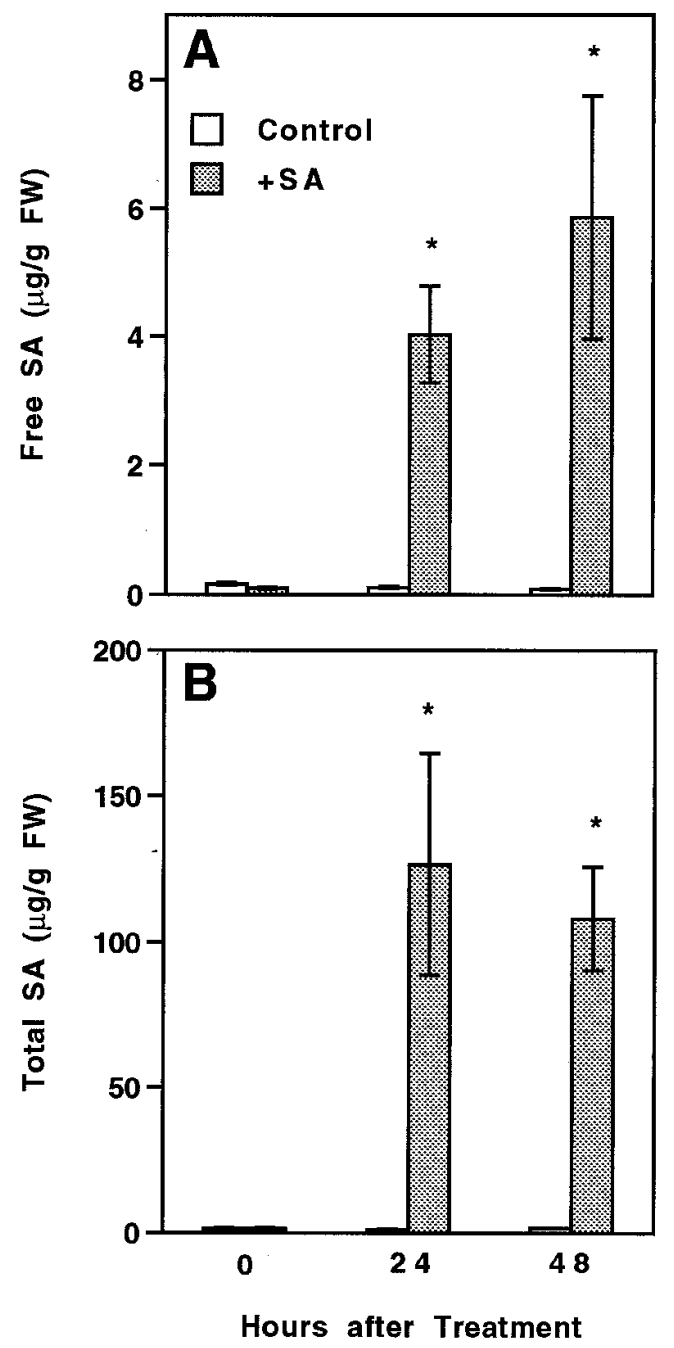

Fig. 1. Foliar levels of $\mathbf{A}$, free and $\mathbf{B}$, total salicylic acid (SA) in control (open bars) and SA-fed (shaded bars) tomato plants. Leaves were harvested 0,24 , and $48 \mathrm{~h}$ after treatment with $0 \mu \mathrm{M} \mathrm{SA}$ (control) or $200 \mu \mathrm{M} \mathrm{SA}$. Data bars are the means ( \pm standard error) of nine replicates. $*$ Indicates a significant difference between the control and SA-fed plants $(P<0.05)$. have been previously shown to decline after $24 \mathrm{~h}$ of feeding hydroponically grown tobacco (11).

SA uptake experiments. To determine if endogenous foliar levels of free and total SA (free SA $+\beta$-glucosylsalicylic acid) changed following exogenous root feeding with $200 \mu \mathrm{M}$ SA, leaf samples were harvested at 0,24 , and $48 \mathrm{~h}$ after SA application. Leaves were obtained from all portions of the plant (major veins excluded), cut into 5-mm-wide pieces, and combined together to ensure heterogeneity of tissue age. Leaf samples $(500 \mathrm{mg})$ were flash-frozen in liquid nitrogen and stored at $-80^{\circ} \mathrm{C}$ until analyzed for SA content.

Pathogen procedures. To maintain cultures, A. solani was subcultured biweekly to modified cornmeal (MCM) agar (1.7\% cornmeal agar, $0.2 \%$ glucose, $0.3 \%$ sucrose, and $0.1 \%$ yeast extract, $\mathrm{wt} / \mathrm{vol}$ ). Cultures displayed a gray, velvet-like appearance on MCM agar. To induce sporulation, mycelia plugs were cut from MCM plates and subcultured onto freshly prepared MCM agar. The fungus was grown at $24 \pm 1^{\circ} \mathrm{C}$ with a 12 -h photoperiod consisting of a combination of UV-C (15-watt germicidal; General Electric, Cleveland) and fluorescent light sources (16). After 8 days of growth under UV-C light, the fungus sporulated as evidenced by the production of several concentric rings of dark conidia. Conidia were harvested by applying $2 \mathrm{ml}$ of sterile deionized $\mathrm{H}_{2} \mathrm{O}$ to the culture plate and gently scraping with a glass microscope slide. The conidial suspension was filtered through a $0.5-\mathrm{mm}^{2}$-pore strainer to
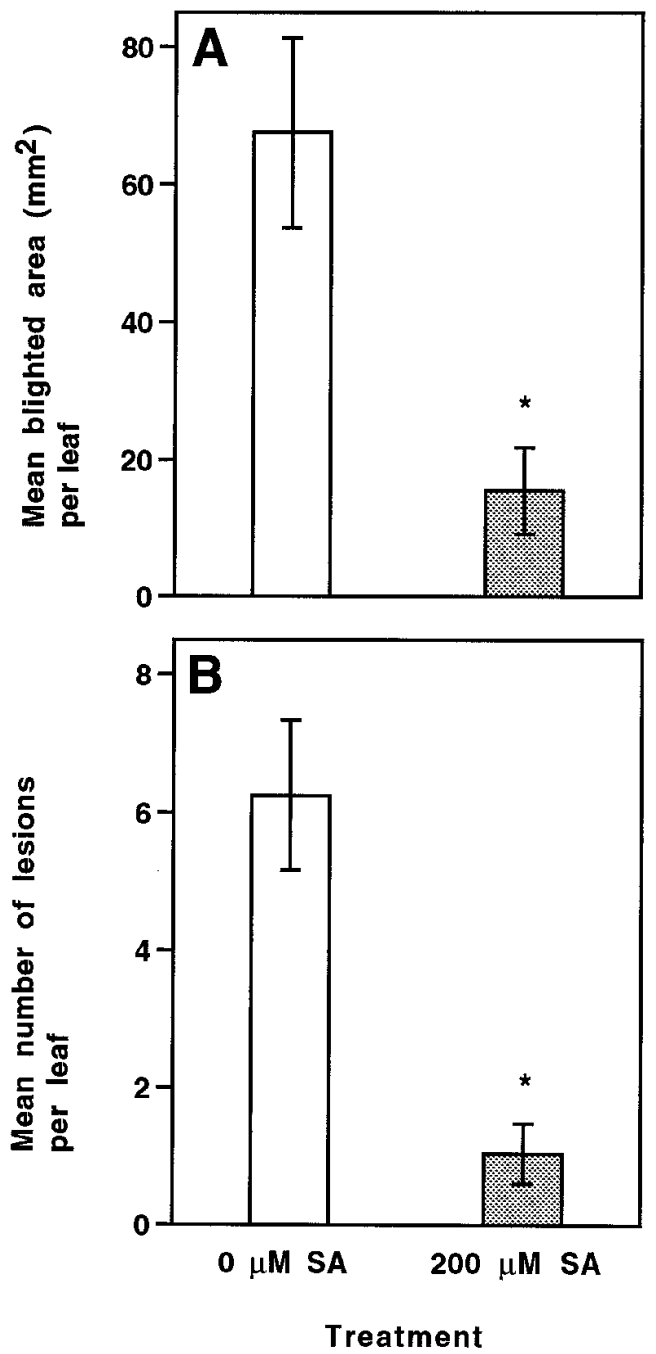

Fig. 2. Systemic protection of tomato foliage against Alternaria solani infection by way of root feeding with $200 \mu \mathrm{M}$ salicylic acid (SA). A, Mean blighted leaf area $\left(\mathrm{mm}^{2}\right)$ and $\mathbf{B}$, mean number of lesions per leaf $120 \mathrm{~h}$ after inoculation with conidia. Data bars are the means ( \pm standard error) of 12 replicates. * Indicates a significant difference between control and $200 \mu \mathrm{M}$ SA-fed plants $(P<0.05)$. 
remove mycelial debris. The resulting spore suspension was diluted to $1 \times 10^{4}$ conidia per $\mathrm{ml}$ and stored at $5^{\circ} \mathrm{C}$.

Infection procedures. Tomato plants provided either $0.5 \times \mathrm{MS}$ solution or $200 \mu \mathrm{M}$ SA in $0.5 \times$ MS solution were inoculated by atomizing the leaves with $8 \mathrm{ml}$ of the conidial suspension. To facilitate conidial germination, plants were maintained at $24 \pm$ $1{ }^{\circ} \mathrm{C}$ within a specially constructed humidity chamber. Plants inside the humidity chamber were provided a 16 -h photoperiod, and an ultrasonic humidifier was utilized to elevate the relative humidity during the 8-h dark period. Leaves appeared completely misted following elevated humidity periods. Plants were allowed to acclimate to conditions of elevated night-time humidity for $48 \mathrm{~h}$ prior to inoculation with A. solani. Lesions first appeared $96 \mathrm{~h}$ following inoculation. Leaf tissue samples $(500 \mathrm{mg})$ were obtained at 0 and $120 \mathrm{~h}$ after inoculation for free SA determination. The extent of disease symptoms was deter-

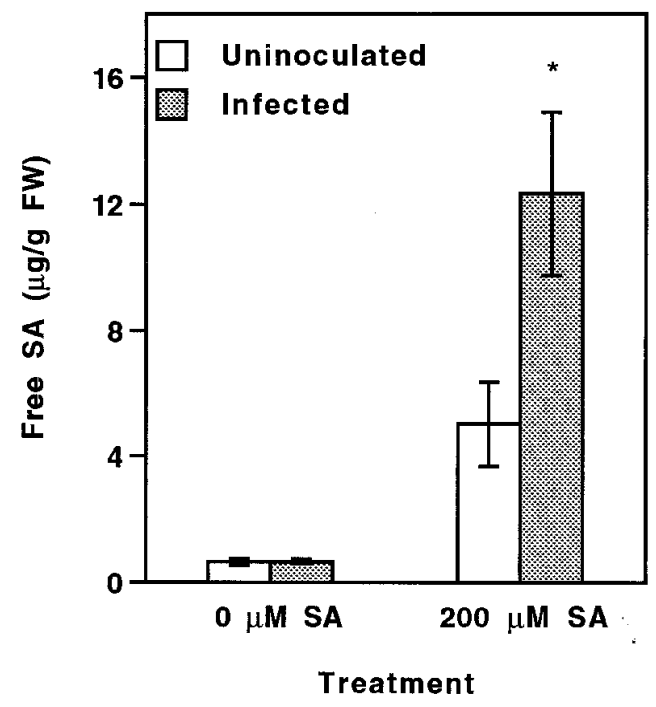

Fig. 3. Foliar levels of free salicylic acid (SA) in uninoculated leaves (open bars) and in Alternaria solani-infected leaves (shaded bars) $120 \mathrm{~h}$ after inoculation with conidia. Data bars are the means ( \pm standard error) of 12 replicates. * Indicates a significant difference between uninoculated and infected plants $(P<0.05)$. mined by measuring the area in square millimeters of the necrotic lesions present on the second oldest compound leaf 5 days after inoculation (5).

Determination of SA. Free and total SA (free SA + $\beta$-glucosylsalicylic acid) were extracted from tomato leaf tissue (500-mg sample) and quantified by spectrofluorescence high-performance liquid chromatography using a modified method of Enyedi and Raskin (9). To determine the $\beta$-glucosylsalicylic acid (SA-glucose conjugate) content, the methanolic leaf extract was dried and resuspended in $1.25 \mathrm{ml}$ of hydrolysis buffer $(100 \mathrm{mmol}$ of sodium acetate buffer per liter, pH 5.5, containing 20 units of $\beta$-glucosidase [EC 3.2.1.21; almond]). After $1.5 \mathrm{~h}$ of incubation at $37^{\circ} \mathrm{C}$, extracts were acidified to $\mathrm{pH} 1.0$ with $10 \%$ (wt/vol) trichloroacetic acid and subjected to SA extraction and quantitation (9). All data were corrected for SA recovery, which ranged from 30 to $35 \%$.

Effect of SA on the radial growth of $A$. solani. The direct effect of SA on growth of $A$. solani was tested in vitro using MCM medium amended with SA concentrations ranging from 0 to $200 \mu \mathrm{M}$. The colony diameter was determined 9 days after inoculation with a 3-mm-diameter plug of $A$. solani mycelium.

RNA isolation and gel blot analysis. In tobacco, the expression of PR-1 mRNA is a positive marker of the development of SAR (35). To investigate the expression of the PR-1B gene (20) in tomato in response to SA treatment, total RNA was isolated by grinding $100 \mathrm{mg}$ of leaf tissue in $1.25 \mathrm{ml}$ of Tri Reagent (MRC Inc., Cincinnati) according to the manufacturer's recommended protocol. Equal amounts of RNA ( $10 \mu \mathrm{g}$ determined from optical density values at $260 \mathrm{~nm}$ ) were subjected to electrophoresis on a $1.2 \%$ (wt/vol) formaldehyde agarose gel and blotted onto Duralon-UV membranes (Stratagene Inc., La Jolla, CA), as described by Ausubel et al. (4), using the Turbo-Blotter system (Schleicher \& Schuell, Keene, NH). Filters were UV cross-linked using a UV Crosslinker (Fisher Scientific Co., Pittsburgh). The membranes were prehybridized and hybridized as described previously (4) with ${ }^{32} \mathrm{P}$-labeled $\left(10^{6}\right.$ to $10^{7}$ counts per min per $\mu \mathrm{g}$ ) cDNA using Quik-Hyb Solution (Stratagene Inc.). The ${ }^{32} \mathrm{P}$-probe used was a 348-bp DNA fragment containing the PR-1B coding sequence cloned from tomato (20). Following hybridization, membranes were washed twice in $6 \times \mathrm{SSPE}$ ( $1 \times \mathrm{SSPE}$ is $0.18 \mathrm{M} \mathrm{NaCl}, 10 \mathrm{mM} \mathrm{NaPO}_{4}$, and $1 \mathrm{mM}$ EDTA, pH 7.7) containing $0.1 \%$ sodium dodecyl sulfate (SDS) for $15 \mathrm{~min}$ at room temperature. An additional high-stringency wash was performed with $0.2 \times \mathrm{SSPE}$ containing $0.1 \% \mathrm{SDS}$ for $30 \mathrm{~min}$ at $68^{\circ} \mathrm{C}$.

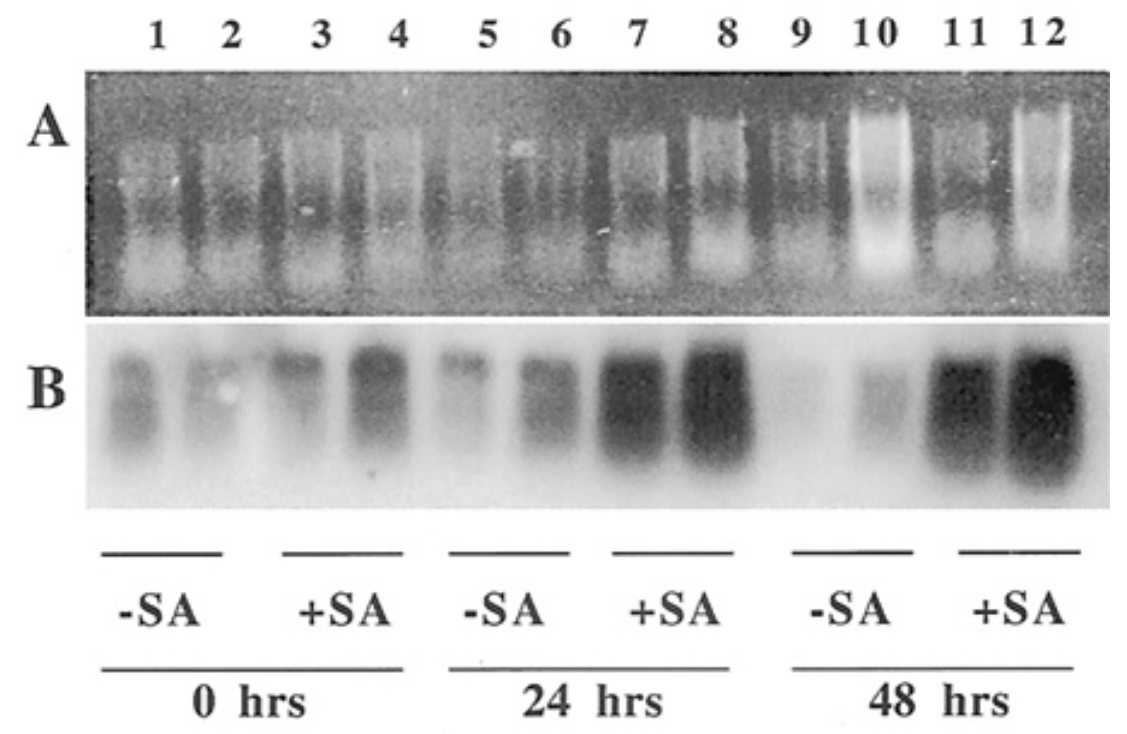

Fig. 4. RNA gel blot analysis of total RNA extracted from tomato leaves following treatment with $0 \mu \mathrm{M}$ salicylic acid (SA) (control) or $200 \mu \mathrm{M}$ S A. Leaf samples were harvested at 0,24 , and $48 \mathrm{~h}$ after the addition of SA. Ten micrograms of total RNA was loaded per lane. Lanes 1, 3, 5, 7, 9, and 11 and lanes 2, 4, 6, 8, 10, and 12 represent two independent SA-feeding experiments. A, Appearance of ethidium bromide-stained gel showing rRNAs and gel loading prior to transfer to Duralon-UV membrane. B, Appearance of blot probed under high-stringency conditions using the 338-bp fragment of tomato PR-1B cDNA. 
The membranes were exposed to X-ray film at $-80^{\circ} \mathrm{C}$ in the presence of an intensifying screen for 2 days.

Statistics. All experiments were carried out using a complete randomized experimental design (31) with three or four replicates per treatment. All experiments were repeated a minimum of three times and exhibited similar trends. Since the outcomes of the experiments were similar, data from all experiments were combined and subjected to reanalysis. An analysis of variance (ANOVA) was used in which variances, as determined by Hartley's equal variance test (31), were within the assumptions of the parametric ANOVA. In circumstances of unequal variance, significance was determined at $P<0.05$ using the Mann Whitney U nonparametric test between treatments (31). The statistical analysis was performed using StatView software for the Macintosh computer (Abacus Concepts, Berkeley, CA).

\section{RESULTS}

Effect of exogenous SA application to tomato. Tomato plants did not exhibit outward signs of transplantation shock following the transfer from the artificial soil medium to the hydroponics vessels. Introduction of $200 \mu \mathrm{M}$ SA in $0.5 \times$ MS medium to the roots caused no apparent change in leaf turgor (visual assessment) or outward signs of phytotoxicity on the foliage. In a preliminary study, tomato plants treated with $500 \mu \mathrm{M}$ SA exhibited a loss of leaf turgor as evidenced by leaf wilting (M. E. Spletzer and A. J. Enyedi, unpublished data). Twenty-four hours after treatment with $200 \mu \mathrm{M} \mathrm{SA}$, the endogenous level of free SA significantly increased to $4.02 \pm$ $0.75 \mu \mathrm{g} \mathrm{g}^{-1}$ fresh weight (FW) from a basal level of $0.09 \pm 0.01 \mu \mathrm{g} \mathrm{g}^{-1}$ FW (Fig. 1A). After $48 \mathrm{~h}$, the endogenous level of SA had significantly increased 65 -fold to $5.85 \pm 1.89 \mu \mathrm{g} \mathrm{g}^{-1} \mathrm{FW}$ when compared with basal SA levels. Similarly, there was significant increase in the endogenous level of total SA after $24 \mathrm{~h}$ to $126.6 \pm 38.0 \mu \mathrm{g} \mathrm{g}^{-1} \mathrm{FW}$ from a basal level of $1.48 \pm 0.17 \mu \mathrm{g} \mathrm{g}^{-1} \mathrm{FW}$. At $48 \mathrm{~h}$, the level of total SA in tomato leaves was $108.0 \pm 17.7 \mu \mathrm{g} \mathrm{g}^{-1} \mathrm{FW}$ (Fig. 1B).

Effect of exogenous $\mathrm{SA}$ feeding on subsequent infection by A. solani. The addition of SA to the liquid root medium significantly affected infection and lesion development in response to $A$. solani inoculation (Fig. 2). The number of lesions per leaf and the total blighted tissue area were significantly reduced when plants were grown in the presence of $200 \mu \mathrm{M} \mathrm{SA}$. Tomato plants inoculated with $A$. solani conidia, but not receiving exogenous SA treatment, exhibited approximately 4.8 times more blighted leaf area than the SA-treated plants $\left(67.5 \pm 15.4 \mathrm{~mm}^{2}\right.$ per leaf versus $13.8 \pm$ $6.9 \mathrm{~mm}^{2}$ per leaf) and 5.6 times more lesions than SA-treated plants $(6.25 \pm 1.0$ lesions per leaf versus $1.1 \pm 0.4$ lesions per leaf) on the second oldest compound leaf. The naturally occurring endogenous level of free SA did not significantly change in response to infection by A. solani (Fig. 3). However, tomato plants with preexisting elevated levels of foliar SA in response to the $200 \mu \mathrm{M}$ SA pretreatment significantly accumulated 2.4 times more SA following A. solani infection as compared with uninoculated plants (Fig. 3).

Effect of SA on PR-1B gene expression. PR-1B mRNA accumulation was induced by SA treatment in tomato leaves (Fig. 4). The accumulation of the PR-1B transcript was induced $24 \mathrm{~h}$ after treatment with $200 \mu \mathrm{M}$ SA. The PR-1B mRNA continued to be strongly expressed at the 48-h time point. There was no induction or additional expression of PR-1B transcripts in leaves not treated with SA during the identical time period (Fig. 4).

Direct effect of SA on the in vitro growth of $A$. solani. The mycelial growth of $A$. solani was not affected by SA amendment of the MCM culture medium (Fig. 5). The mean colony diameter of $A$. solani was not significantly different when directly exposed to SA concentrations ranging from 0 to $200 \mu \mathrm{M}$.

\section{DISCUSSION}

In this series of experiments, we demonstrated that SA can activate a form of systemic resistance against $A$. solani in hydroponi- cally grown tomato plants. This was accomplished by providing $200 \mu \mathrm{M}$ SA directly to the root system of the plant. Foliar application of SA to tomato has been previously attempted, but is an ineffective method for the introduction of SA to the leaf interior (32). Our investigations clearly demonstrate that root feeding of SA to tomato is an effective method of SA incorporation as compared with exogenous SA application to the leaf surface. Root feeding of SA also activates SAR in tomato; however, it is not known if foliar application of SA has the same effect (32).

In each experiment performed, there was a significant decrease in the incidence of disease when the pathogen inoculation was preceded by SA treatment. SA is known to be a potent inducer of systemic resistance in tobacco, cucumber, potato, and arabidopsis $(7,20,35,37)$; consequently, it is not surprising that SA exerts a similar effect in tomato. In tomato, SAR can be induced using several different biotic elicitors; however, there are no reports of induction of SAR in tomato using the direct application of SA. Earlier work has shown that inoculation with $P$. infestans $(8,13)$, tobacco necrosis virus (3), and the host-incompatible Meloidogyne incognita nematode (28) all induce SAR in tomato. However, any changes in the levels of endogenous SA following elicitation were not determined in any of these studies $(3,8,13,28)$.

Because SA is an important signal molecule $(8,15)$, its level may increase endogenously prior to the activation of SAR in each of the host-pathogen interactions described above $(21,24)$. In the current study, the acquisition of systemic resistance to A. solani in tomato tightly correlated with elevated endogenous SA levels and the expression of the PR-1B gene. Artificially elevating the level of SA in hydroponically grown tobacco has also been shown to induce SAR and provide protection against tobacco mosaic virus (11). The minimum level of SA that is required to activate SAR in tobacco is approximately $0.33 \mu \mathrm{g} \mathrm{g}^{-1} \mathrm{FW}$ (39) — this supports our observation of SAR induction in tomato at foliar levels of $4.02 \mu \mathrm{g} \mathrm{g}^{-1} \mathrm{FW}$. Plants that did not receive SA consistently had larger lesion areas and greater numbers of lesions per leaf and were unable to induce the expression of PR-1B mRNA. Following pathogen infection, increased levels of SA are known to occur $(11,21,24)$. In our experiments, pathogen infection of SA-fed plants resulted in a significant increase in the level of free SA (Fig. 2). Currently, it is unclear why SA levels should fluctuate following plant pathogen infection from initial elevated SA levels; however, we are investigating this response further. Plants that did not receive the $200 \mu \mathrm{M}$ SA treatment exhibited

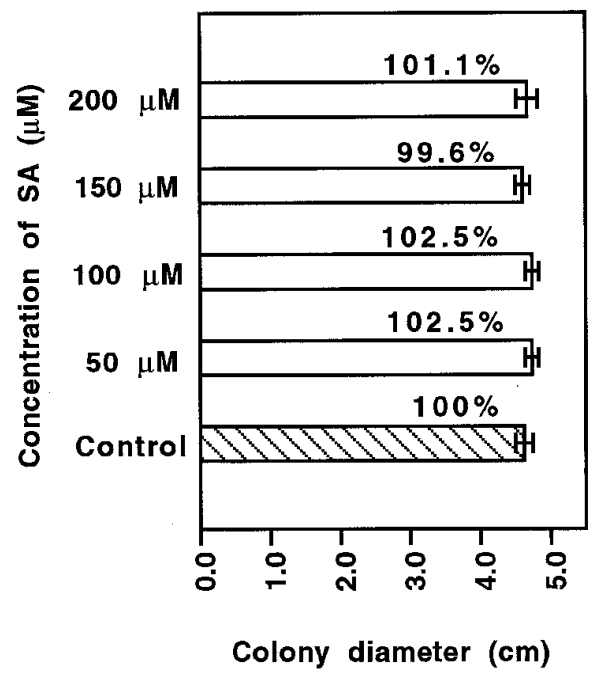

Fig. 5. Effect of salicylic acid (SA) on the radial growth of Alternaria solani in culture. Fungal colonies were reared on modified cornmeal medium amended with 0 (control), 50, 100, 150, or $200 \mu \mathrm{M}$ SA. Data bars are the means ( \pm standard error) of nine replicates. Percent values listed above each data bar represent radial growth compared with the control. No significant difference $(P<$ 0.05 ) in colony diameters was found. 
no significant change of endogenous SA levels following infection by A. solani. It might be interpreted that, during conditions of elevated foliar SA, pathogen infection can either (i) induce the de novo synthesis of SA or (ii) enhance the uptake of SA from the liquid medium; both of these possibilities are being investigated.

In contrast to an earlier report of the effect of feeding SA to an excised tomato leaf (32), we have carefully characterized the temporal change in foliar SA levels in response to SA feeding. Feeding SA to $A$. solani-susceptible tomato plants grown hydroponically results in a significant increase in the basal level of SA in healthy, uninoculated leaves. The levels of both free and total SA increased within $24 \mathrm{~h}$ of the addition of $200 \mu \mathrm{M}$ SA to the hydroponic solution. A similar response has been observed for tobacco treated with $100 \mu \mathrm{M}$ SA (11). This indicates that the root system of tomato has the capacity to assimilate SA, distribute the compound throughout the plant, and ultimately activate systemic disease resistance. It is interesting to note that within $48 \mathrm{~h}$ of SA application, the majority of the extractable foliar SA in tomato leaves was found to exist as $\beta$-glucosylsalicylic acid (9). Thus, tomato appears to possess a glucosyltransferase enzyme similar in function and activity to the enzyme found in tobacco and oat $(9,38)$.

It is important to distinguish whether SA was directly responsible for reduced diseased symptoms (possibly acting as a fungicidal compound in situ) or if SA acted indirectly by activating an as-yet-unidentified signal transduction pathway involved in tomato $\mathrm{SAR}$. In our study, SA-amended media (concentration range of 0 to $200 \mu \mathrm{M} \mathrm{SA}$ ) were utilized to determine the response of $A$. solani to SA (Fig. 5). Using our data from the SA feeding experiment, we observed $5.85 \mu \mathrm{g}$ of free SA per g of leaf tissue (Fig. 1). Based on this value, this is equivalent to a $47.1 \mu \mathrm{M}$ SA tissue concentration using a $90 \%$ (wt/wt) tissue water content level (data not shown). Regardless of the SA concentration used in MCM agar, there was no significant decrease in the radial growth of $A$. solani mycelium. This indicates that SA does not have a direct antifungal affect on $A$. solani, but rather serves to trigger the signal transduction pathway that ultimately gives rise to $\operatorname{SAR}(8,15)$.

Although this is the first report of SAR that is specific for $A$. solani in tomato, several examples exist in the literature that show that induced systemic resistance can be effective against Alternaria sp. fungi in other plant species $(7,14,36)$. Systemic resistance to $A$. cassiae in sicklepod ( $C$. obtusifolia) has been induced using a foliar application of 1,000 $\mu \mathrm{M} \mathrm{SA}$ (36). This report supports our finding that reduced disease incidence can be achieved by way of pretreatment with SA. Systemic resistance to A. brassicola has been induced using Pseudomonas fluorescens strain WCS417 (14), and the foliar application of arachidonic acid to potato activates SAR against $A$. solani (7). Arachidonic acid appears to cause an increase in the endogenous, free SA levels (7), and this is consistent with our observation that SAR in tomato occurs in concert with elevated SA levels.

SA-induced resistance to $A$. solani is likely due to the elicitation of a set plant defense responses $(8,15)$. PR proteins (34) are considered to constitute one important portion of the induced defense responses employed by SAR $(10,15,33)$. When we analyzed the expression of PR-1B mRNA transcripts following SA treatment, we found elevated expression of PR-1B mRNA at both 24- and 48 -h time points. This increase in PR-1B expression paralleled the increase in foliar SA concentrations depicted in Figure 1. Induction of PR gene expression following SA application has also been demonstrated in tobacco, arabidopsis, and cucumber plants $(24,35)$. Van Kan et al. (32) report a similar finding after $24 \mathrm{~h}$ for an extracellular PR-1 transcript (P6) following SA feeding of an excised tomato leaf; however, this particular study made no distinction between PR-1A, PR-1B, or PR-1C genes. The PR gene families have been particularly well characterized in tobacco (35), but this is not the case for tomato. Although these proteins have drawn considerable interest, due largely to their induction during SAR, very little is known regarding the function and activity of the PR-1 protein family in tomato. Alexander et al. (2) reported indirect evidence of antifungal activity of PR-1a protein in tobacco. In tomato, PR-1 family proteins have been demonstrated to have antifungal properties against $P$. infestans and Cladosporium fulvum (27,33); however, no assay was performed using $A$. solani.

The goal of this investigation was to determine if an increase in endogenous SA levels in tomato by way of artificial means would alter the susceptibility of foliage to A. solani. By comparing foliar disease symptoms in SA-fed versus control plants, we can conclude that SA feeding does reduce susceptibility to $A$. solani, likely due, in part, to the expression of the PR-1B gene and subsequent induction of SAR. The PR-1 family of genes are reliable markers of SAR $(15,35)$, and SA strongly induced the expression of the PR-1B gene in tomato. Because White (37) has previously shown that exogenous SA application to tobacco can activate SAR, this raises the interesting possibility that SA could be used as an amendment in the nutrient solution of other hydroponically grown vegetable crops. This use of SA may be particularly valuable for hyroponic tomato crops susceptible to both A. solani and Botrytis cinerea (gray mold) infection (16).

\section{ACKNOWLEDGMENTS}

This work was supported by a grant to A. J. Enyedi from the Asgrow Seed Company. We thank J. P. Hubbard of the Asgrow Seed Company (Bacterial and Foliar Diseases Division) for providing the virulent isolate of Alternaria solani and S. T. Lund, Department of Horticultural Sciences, University of Florida, for providing the PR-1B cDNA probe.

\section{LITERATURE CITED}

1. Agrios, G. N. 1998. Plant Pathology. 4th ed. Academic Press Inc., New York.

2. Alexander, D., Goodman, R. M., Gut-Rella, M., Glascock, C., Weymann, K., Friedrich, L., Maddox, D., Ahl-Goy, P., Luntz, T., Ward, E., and Ryals, J. 1993. Increased tolerance to two oomycete pathogens in transgenic tobacco expressing pathogenesis-related protein 1a. Proc. Natl. Acad. Sci. U.S.A. 90:7327-7331.

3. Anfoka, G., and Buchenauer, H. 1997. Systemic acquired resistance in tomato against Phytophthora infestans by pre-inoculation with tobacco necrosis virus. Physiol. Mol. Plant Pathol. 50:85-101.

4. Ausubel, F. M., Brent, R., Kingston, R. E., Moore, D. D., Seidman, J. G., Smith, J. A., and Struhl, K. 1992. Short Protocols in Molecular Biology. John Wiley \& Sons, New York.

5. Barksdale, T. H. 1971. Field evaluation for tomato early blight resistance. Plant Dis. Rep. 55:807-809.

6. Chester, K. S. 1933. The problem of acquired physiological immunity in plants. Q. Rev. Biol. 8:275-324.

7. Coquoz, J.-L., Buchala, A. J., Meuwly, P., and Métraux, J.-P. 1995. Arachidonic acid induces local but not systemic synthesis of salicylic acid and confers systemic resistance in potato plants to Phytophthora infestans and Alternaria solani. Phytopathology 85:1219-1224.

8. Enkerli, J., Gisi, U., and Mosinger, E. 1993. Systemic acquired resistance to Phytophthora infestans in tomato and the role of pathogenesis related proteins. Physiol. Mol. Plant Pathol. 43:161-171.

9. Enyedi, A. J., and Raskin, I. 1993. Induction of UDP-glucose: Salicylic acid glucosyltransferase activity in tobacco mosaic virus-inoculated tobacco (Nicotiana tabacum) leaves. Plant Physiol. 101:1375-1380.

10. Enyedi, A. J., Yalpani, N., Silverman, P., and Raskin, I. 1992. Signal molecules in systemic plant resistance to pathogens and pests. Cell 70:879-886.

11. Enyedi, A. J., Yalpani, N., Silverman, P., and Raskin, I. 1992. Localization, conjugation, and function of salicylic acid in tobacco during the hypersensitive reaction to tobacco mosaic virus. Proc. Natl. Acad. Sci. U.S.A. 89:2480-2484.

12. Friedrich, L., Lawton, K., Dincher, S., Winter, A., Staub, T., Uknes, S., Kessmann, H., and Ryals, J. 1993. Benzothiadiazole induces systemic acquired resistance in tobacco. Plant J. 10:61-70.

13. Heller, W. E., and Gessler, C. 1986. Induced systemic resistance in tomato plants against Phytophthora infestans. J. Phytopathol. 116:323-328.

14. Hoffland, E., Hakulinen, J., and van Pelt, J. A. 1996. Comparison of systemic resistance induced by avirulent and nonpathogenic Pseudomonas species. Phytopathology 86:757-762.

15. Hunt, M. D., and Ryals, J. A. 1996. Systemic acquired resistance signal transduction. Crit. Rev. Plant Sci. 15:583-606.

16. Jones, J. B., Jones, J. P., Stall, R. E., and Zitter, T. A. 1991. Infectious 
diseases: Diseases caused by fungi. Pages 9-25 in: Compendium of Tomato Diseases. The American Phytopathological Society, St. Paul, MN.

17. Kauffmann, S., Legrand, M., Geoffroy, P., and Fritig, B. 1987. Biological function of pathogenesis-related proteins: Four PR proteins of tobacco have 1,3- $\beta$-glucanase activity. EMBO (Eur. Mol. Biol. Organ.) J. 6:3209-3212.

18. Lawton, K., Friedrich, L., Hunt, M., Weymann, K., Staub, T., Kessmann, H., and Ryals, J. 1996. Benzothiadiazole induces disease resistance in Arabidopsis by activation of the systemic acquired resistance signal transduction pathway. Plant J. 10:71-82.

19. Legrand, M., Kauffmann, S., Geoffroy, P., and Fritig, B. 1987. Biological function of pathogenesis-related proteins: Four tobacco pathogenesis-related proteins are chitinases. Proc. Natl. Acad. Sci. U.S.A. 84:6750-6754.

20. Lund, S. T., Stall, R. E., and Klee, H. J. 1998. Ethylene regulates the susceptible response to pathogen infection in tomato. Plant Cell 10:371-382.

21. Malamy, J., Carr, J. P., Klessig, D. F., and Raskin, I. 1990. Salicylic acid: A likely endogenous signal in the resistance response of tobacco to viral infection. Science 250:1002-1004.

22. Malamy, J., Hennig, J., and Klessig, D. F. 1992. Temperature-dependent induction of salicylic acid and its conjugate during the resistance response to tobacco mosaic virus infection. Plant Cell 4:359-366.

23. Métraux, J.-P., Ahl-Goy, P., Staub, T., Speich, J., Steinemann, A., Ryals, J., and Ward, E. 1991. Induced resistance in cucumber in response to 2,6-dichloroisonicotinic acid and pathogens. Pages $432-439$ in: Advances in Molecular Genetics of Plant-Microbe Interactions, Vol. 1. H. Hennecke and D. P. S. Verma, eds. Kluwer Academic Publishers, Dordrecht, the Netherlands.

24. Métraux, J.-P., Signer, H., Ryals, J., Ward, E., Wyss-Benz, M., Gaudin, J., Raschdorf, K., Schmid, E., Blum, W., and Inverardi, B. 1990. Increase in salicylic acid at the onset of systemic acquired resistance in cucumber. Science 250:1004-1006.

25. Murashige, T., and Skoog, F. 1962. A revised medium for rapid growth and bioassays with tobacco tissue cultures. Physiol. Plant. 15:473-497.

26. Nash, A. F., and Gardner, R. G. 1988. Heritability of tomato early blight resistance derived from Lycopersicon hirsutum P.I. 126445. J. Am. Soc. Hortic. Sci. 113:268.

27. Niderman, T., Genetet, I., Bruyère, T., Gees, R., Stintzi, A., Legrand, M., Fritig, B., and Mösinger, E. 1995. Pathogenesis-related PR-1 proteins are antifungal. Plant Physiol. 108:17-27.

28. Ogallo, J. L., and McClure, M. A. 1996. Systemic acquired resistance and susceptibility to root-knot nematodes in tomato. Phytopathology 86 : 498-501.

29. Palva, T. K., Hurtig, M., Saindrenan, P., and Palva, E. T. 1994. Salicylic acid induced resistance to Erwinia carotovora subsp. carotovora in tobacco. Mol. Plant-Microbe Interact. 7:356-363.

30. Ross, A. F. 1961. Systemic acquired resistance induced by localized virus infections in plants. Virology 14:329-339.

31. Snedecor, G. W., and Cochran, W. G. 1980. Statistical Methods. 7th ed. The Iowa State University Press, Ames.

32. Van Kan, J. A. L., Cozijnsen, T., Danash, N., and de Wit, P. J. G. M. 1995. Induction of tomato stress protein mRNAs by ethephon, 2,6-dichloroisonicotinic acid and salicylate. Plant Mol. Biol. 27:1205-1213.

33. Van Kan, J. A. L., Joosten, M. H. A. J., Wagemakers, C. A. M., van den Berg-Velthuis, G. C. M., and de Wit, P. J. G. M. 1992. Differential accumulation of mRNAs encoding extracellular and intracellular PR proteins in tomato induced by virulent and avirulent races of Cladosporium fulvum. Plant Mol. Biol. 20:513-527.

34. Vernooij, B., Friedrich, L., Ahl Goy, P., Staub, T., Kessmann, H., and Ryals, J. 1995. 2,6-Dichloroisonicotinic acid-induced resistance to pathogens without the accumulation of salicylic acid. Mol. Plant-Microbe Interact. 8:228-234.

35. Ward, E. R., Uknes, S. J., Williams, S. C., Dincher, S. S., Wiederhold, D. L., Alexander, D. C., Ahl-Goy, P., Métraux, J.-P., and Ryals, J. A. 1991. Coordinate gene activity in response to agents that induce systemic acquired resistance. Plant Cell 3:1085-1094.

36. Weete, J. D. 1992. Induced systemic resistance to Alternaria cassiae in sicklepod. Physiol. Mol. Plant Pathol. 40:437-445.

37. White, R. F. 1979. Acetylsalicylic acid (aspirin) induces resistance to tobacco mosaic virus in tobacco. Virology 99:410-412.

38. Yalpani, N., Schulz, M., Davis, M. P., and Balke, N. E. 1992. Partial purification and properties of an inducible uridine $5^{\prime}$-diphosphate-glucose:salicylic acid glucosyltransferase from oat roots. Plant Physiol. 100: 457-463.

39. Yalpani, N., Silverman, P., Wilson, T. M. A., Kleir, D. A., and Raskin, I. 1991. Salicylic acid is a systemic signal and an inducer of pathogenesisrelated proteins in virus-infected tobacco. Plant Cell 3:809-818. 